\title{
Geociências
}

\section{Geochemistry of hematitite and itabirite, Quadrilátero Ferrífero, Brazil}

\author{
(Geoquímica de hematitito e itabirito, \\ Quadrilátero Ferrífero, Brasil)
}

\begin{abstract}
Moustafa Selmi
Doutorando do Departamento de Geologia, Escola de Minas/Universidade Federal de Ouro Preto, MG - Brazil

Email:moustafaselmi@gmail.com.

Leonardo E. Lagoeiro

Departamento de Geologia - Escola de Minas/ Universidade Federal de Ouro Preto, MG - Brazil

E-mail: lagoeiro@degeo.ufop.br

Issamu Endo

Departamento de Geologia - Escola de Minas/Universidade Federal de Ouro Preto, MG - Brazil

E-mail: issamu@degeo.ufop.br
\end{abstract}

\section{Resumo}

Foram coletadas 21 amostras de hematitito e 12 amostras de itabirito em diferentes depósitos do Quadrilátero Ferrífero (QF) e a partir de análises geoquímicas foram obtidos dados referentes aos elementos-traço e elementos terras-raras (ETR). O objetivo é entender a distribuição dos elementos analisados no QF em comparação com formações ferríferas $(\mathrm{FF})$ ao redor do mundo. O conteúdo de elementos-traço é relativamente baixo com considerável variabilidade e é inferior aos das FF de Algoma, Anamikie, Maru na Nigéria e Orissa na Índia. A abundância de ETR é relativamente baixa, porém superior à de Hamersley na Austrália Ocidental, Surgur na Índia e inferior à de Kuruman na África do Sul. O padrão normalizado por condrito mostra um leve grau de fracionamento de ETR leves em relação aos ETR pesados, fracas anomalias positivas de Eu, além de altos valores para a relação $(\mathrm{La} / \mathrm{Yb})_{\mathrm{CN}} \mathrm{e}$ $(\mathrm{La} / \mathrm{Sm})_{\mathrm{CN}}$

Palavras-chave: Geoquímica, formações ferríferas, Quadrilátero Ferrífero, hematitito, itabirito.

\begin{abstract}
Twenty-one samples of hematitite and twelve samples of itabirite were collected from different deposits of the Quadrilátero Ferrifero (QF) area and were analyzed for trace and rare earth elements. The purpose of the study is to understand the element distribution in the $Q F$ in comparison with other iron formations (IF) around the world. Trace element contents are relatively low with considerable variability, being lower than the contents in the Algoma IF, Anamikie IF, Maru IF in Nigeria and Orissa IF in India. REE's abundance is relatively low, but higher than REE's of Hamersley IF of Western Australia, Surgur belt in India and lower than Kuruman IF in South Africa. Chondrite normalized patterns show slight degrees of fractionation for LREE to HREE and slightly positive Eu anomalies coupled with positive values of $(\mathrm{La} / \mathrm{Yb})_{C N}$ and $(\mathrm{La} / \mathrm{Sm})_{C N}$ ratios.

Keywords: Geochemistry, iron formations, Quadrilátero Ferrifero, hematitite, itabirite.
\end{abstract}




\section{Introduction}

The Quadrilátero Ferrífero (QF) is comprised of an approximately square area of ca. $7.000 \mathrm{~km} 2$ and hosts one of the largest iron ore deposits in the world (Figure 1).

Researchers have focused on trace and rare earth elements to reveal the origin of classical iron formations (IFs) around the world, such as in the Algoma district and Lake superior region in Canada (Animikie IF) (Gross and Macleod, 1980), the Hamersley IF in Western Australia (Alibert and Mcculloch, 1993), the Kuruman formation from the Transvaal Supergroup in South Africa (Bau and Dulski, 1996), the Maru IF in Nigeria (Adekoya, 1998) and the iron formations in the Sargur Belt in India (Kato et al., 1996). Geochemical studies on IFs in Brazil, however, are very scarce. Klein and Ladeira (2000) studied samples of the Cauê Formation from the western Quadrilátero Ferrífero (QF) region, regionally known as itabirite, which are similar to some metamorphosed banded iron formations from the Lake Superior region in North America. Based on trace and rare-earth element analyses, itabirite formed by precipitation from mixed Paleoproterozoic seawater and hydrothermal fluids. The chemistry of the dolomitic variety of this rock was investigated by Spier et al. (2007). These authors proposed a similar origin for the dolomitic itabirite. In the QF two main iron rich rocks occur and they are the main iron ore types exploited in the mines. With the purpose of contributing to the understanding of the geochemical characteristics of the itabirite, whole-rock analyses of representative samples collected from different deposits were performed. The samples were separated in two distinct types: hematitite and itabirite depending on their chemical composition. The term itabirite is defined as a laminated, metamorphosed iron formation of iron oxides (hematite, magnetite, martite), abundant in quartz, but very rarely containing mica and other accessory minerals (Dorr and Barbosa, 1963). Hematitite is a high grade iron ore containing more than $90 \%$ of hematite in the modal proportion. Trace and rare earth elements were analyzed in terms of its spatial distributionand variation in samples of the same or different types. The resulting values were then compared values from other banded iron formations around the world.

\section{Geological setting}

The samples analyzed in this study belong to the hematite-magnetite lithofacies of iron formation (IF) in the Quadrilátero Ferrífero region which is located in southern part of the São Francisco Craton (Dorr, 1969) (Fig.1). Two broad compositional types of iron formation occur in the QF area: quartzitic and dolomitic itabirite. IFs of amphibolitic composition can also be found in the QF area, although in much less proportions

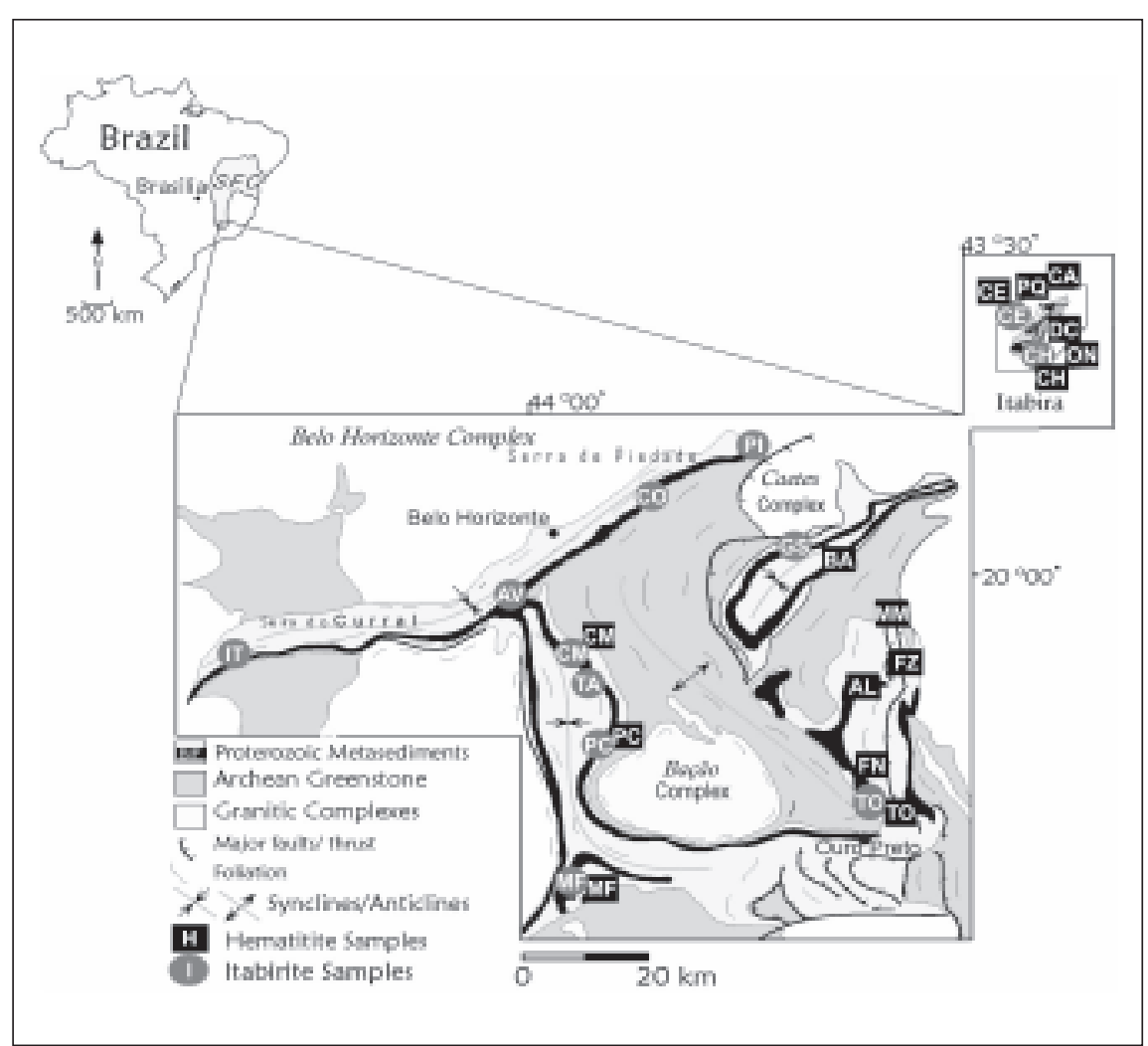

Figure 1 - Simplified geological map of the Quadrilátero Ferrífero (after Dorr, 1969), (SFC) São Francisco Cráton. Sampled iron ore deposits: IT-Itatiaiuçu, AV- AVG Mineração, CO-Córrego do Meio, PI-Piedade, CM-Capitão do Mato, TA-Tamanduá, PC-Pico do Itabirito, MF-Mina de Fábrica, GS-Gongo Soco, BA-Baú, MM-Morro da Mina, FZ-Fazendão, AL-Alegria, FN-Fábrica Nova, TO-Timbopeba, CE-Mina de Conceição, PQ-Mina do Periquito, DC-Mina de Dois Córregos, ON-Mina do Onça, CH-Mina da Chacrinha, CA-Mina de Cauê. 
thrust-and- fault structures associated with the development of pervasive tectonic fabrics (schistosity, mylonitic foliations, crenulation cleavage and mineral stretching lineations) (Chemale et al., 1994).

The QF region has been usually divided into two major tectonic domains (Rosière et al., 2001). The eastern region is considered as a high strain domain with a widespread shear zone development and pervasive structures. By contrast, the deformation in the western portions is typically low. Synclines are preserved and primary structures can be recognized.

The metamorphic grade also increases from the west (lower greenschist facies) to the east (lower amphibolite facies) (Herz, 1978; Pires, 1995). The mineral assemblage indicates temperatures ranging from $300^{\circ} \mathrm{C}$ in the west region to $600^{\circ} \mathrm{C}$ in the east (Pires, 1995).

\section{Mineralogy and petrography}

The analyzed iron-rich rocks are comprised of hematitite and itabirite (Fig. 2 ). The difference between them is the proportion of iron oxide to quartz. The mineral composition of both sample types is characteristically simple. By far the major constituent minerals are hematite, magnetite and quartz. Occasionally, minor to trace amounts of minerals such as tourmaline, apatite and few other silicates, such as amphiboles, may be present, particularly in IFs of the western domain of the QF region. The hematitite is composed basically of hematite (Fig. 2a, b). Magnetite is also present in varied amounts depending on the location of the sampling. It is most commonly found in the western domain of the QF area. The magnetite grains progressively become rare in the iron formation towards the eastern domain as they are progressively transformed to hematite. They are only observed as relict grains immersed in a matrix of hematite crystals. There, magnetite crystals are mostly euhedral and in a large extent oxidized to hematite (Fig. 2c). By contrast, the hematite grains occur in a great variety of shapes. They can be granular (Fig. 2d) with irregular or straight boundaries. Hematite grains of tabular or platy shape (Fig. 2e) are more often observed in the high-strain domains of the QF, particularly in the eastern domain. Hematite grains in these rocks show a strong shape and crystallographic preferred orientation (Morales et al. 2008).

On the other hand, itabirite (Fig. 2f) has remarkable compositional banding with alternating layers of iron oxide and quartz of variable thicknesses. The proportion of iron oxides and quartz in each layer may vary in wide proportions. However pure oxide layers are essentially composed of hematite in granular, tabular or platy shapes. The microstructures of hematite grains in these layers may vary from aggregates of randomly oriented crystals to those where basal planes of hematite are preferred-oriented, usually defining a plane of foliation similar to that of micas (Fig. 2g). In general grain sizes tend to be smaller in the iron formation of the western domain than in their counterparts of the eastern domain.

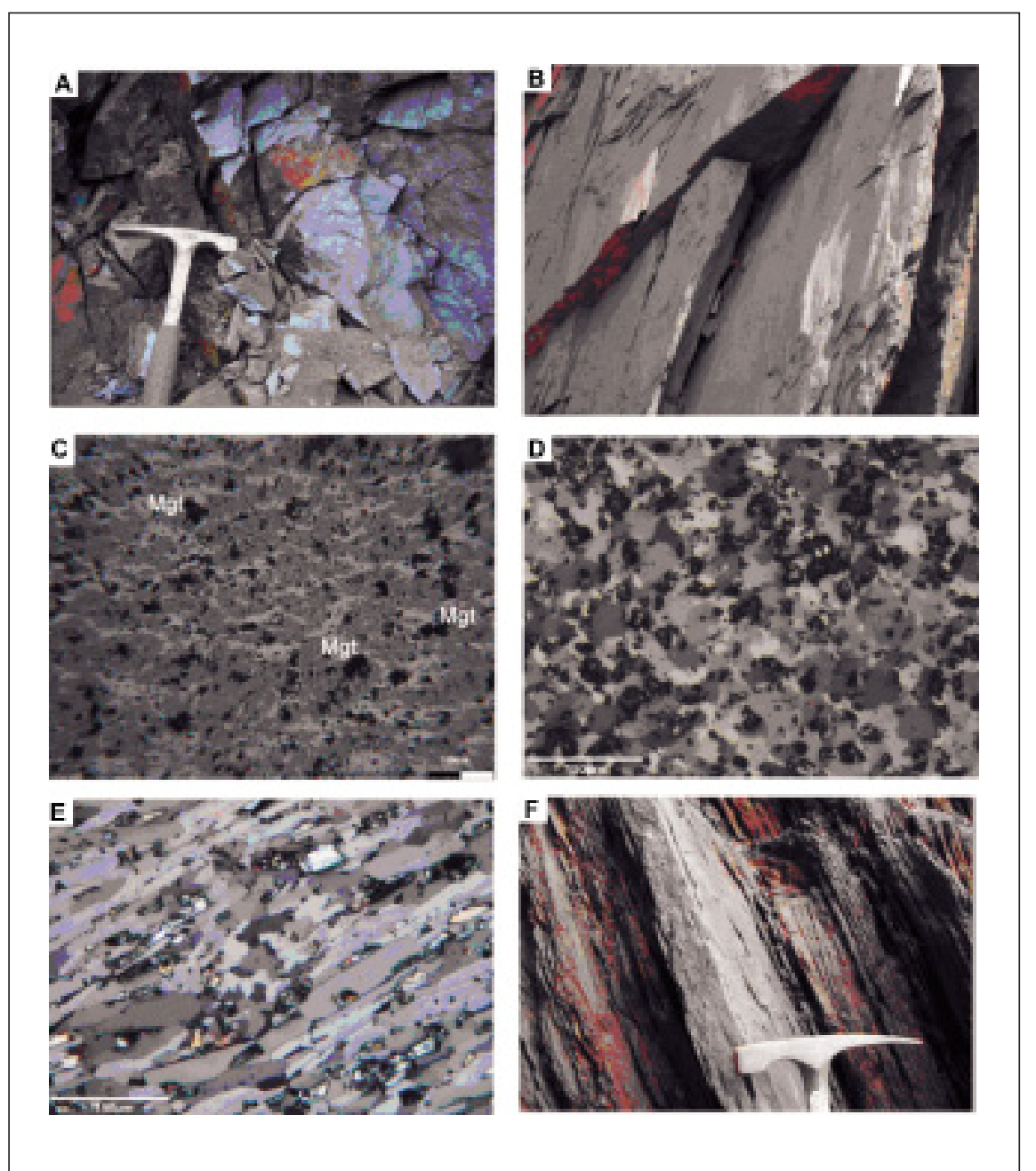

Figure 2 - Features of the analyzed samples. (A) Hematitite with characteristic metallic luster and massive aspect. (B) Foliated type of hematitite. (C) Relicts of martitized crystal of magnetite immersed in euhedral crystals of tabular hematite, polished section. Crossed polarized light. (D) Aggregate of granular hematite crystals in polished section taken from sample (A) under crossed polarized light. (E) Foliated hematite showing a strong preferred orientation of tabular crystals. (F) Outcrop with foliated itabirite. 


\section{Methodology}

Twenty-one samples of hematitite (high grade hematite ores) and twelve of itabirite were analyzed for trace and rare earth elements. We have analyzed only cohesive and fresh samples, e.g. those without any sign of weathering collected from a deep open pit mine. Hematitite samples are chemically more homogeneous even though in some specimens a contrasting arrangement of hematite crystals disposed in alternating bands gives rise to a planar anisotropy similar to those of the itabirite. The samples were cleaned and dried and then crushed to 150 mesh size in a tungsten carbide ringmill. The fine fraction pulverized samples were sent to the ACME Analytical Laboratories Ltd. (Vancouver, BC, Canada) for geochemical analyses. Major and trace elements $\mathrm{Zr}$ and $\mathrm{Y}$ were determined by wavelength dispersive, sequential X-ray fluorescence spectrometer. Selected trace (V, Co, Ni, Cu, Zn, Rb, Sr, Ba, Hf and Ta) and rare-earth elements were determined by inductively coupled plasma mass spectrometry (ICP-MS) at ACME Lab. The limit of detection of trace elements is $>0.5 \mathrm{ppm}$ for the group ( $\mathrm{Hf}, \mathrm{Nb}, \mathrm{Rb}, \mathrm{Sr}, \mathrm{V}, \mathrm{Co}$ ), the limit is $>0.1$ for the group (Y, Ta) and $1 \mathrm{ppm}$ for $\mathrm{Sn}$, whereas, the limit of detection of Rare earth elements is $>0.05 \mathrm{ppm}$ for $(\mathrm{Eu}, \mathrm{Gd}$, Tb, Dy, Yb, Tm, Er, Ho, Lu), while the limit is $>0.1 \mathrm{ppm}$ for $\mathrm{Sm}$ and $>0.4 \mathrm{ppm}$ for $\mathrm{Nd}$.

\section{Results}

\subsection{Trace Elements (TE)}

Thirteen trace elements ( $, \mathrm{Co}, \mathrm{Ni}$, $\mathrm{Cu}, \mathrm{Zn}, \mathrm{Rb}, \mathrm{Sr}, \mathrm{Y}, \mathrm{Zr}, \mathrm{Nb}, \mathrm{Ba}$, Hf and Ta) were determined in the hematitite and itabirite samples (Table 1.). In both ores the trace element contents present a wide range of concentrations similar to the other IFs around the world (Cole, 1981; Adekoya, 1998). Both hematitite and itabirite show similar concentration all over the QF region (Fig. 3).

In the hematitite samples the abundance of the trace elements varies between ca. 23.6 - 262 ppm. Most individual trace elements show wide concentrations. $\mathrm{V}$ is the most abundant with an average of $39 \mathrm{ppm}$. The Co (9 ppm), Ni (5.5ppm), and Y contents (8.2 ppm) also present a wide range of values (1-45.8 ppm). In the lower range of the values appear $\mathrm{Rb}(0.3-6 \mathrm{ppm})$, Sr (0.3-22.7 ppm), Zr (1.7-25.1 ppm), $\mathrm{Nb}$ (0.3-11.3 ppm), Hf(0.3-0.6 ppm) and $\mathrm{Ta}(0.1-0.3 \mathrm{ppm})$. Ba is an important trace element with concentration relatively higher than the last group of trace elements ( $\mathrm{Rb}-\mathrm{Ta})$, but with a large scattering of values (0.3-35.2 ppm). Sample HAl2 has high values of some trace elements such as V, Co, Y, Sr, Ba and $\mathrm{Zr}$.

The concentration of trace elements in the itabirite samples is in average $87.8 \mathrm{ppm}$, and, just as the hematitite, also shows a wide range of values (Table 1). $\mathrm{V}$ and Co are the most abundant. The V values vary from 2.5 to $55 \mathrm{ppm}$ averaging 20.6 ppm (Table 1). The Co concentrations have an average value of around $21.6 \mathrm{ppm}$. The $\mathrm{Ba}$ content averages $13.3 \mathrm{ppm}$ within a wide range of values (0.3 - 66.1ppm). Hf and Ta present very low concentrations with an average of 0.3 ppm similar to the $\mathrm{Rb}$ content. The average concentration of the other trace elements is very low with high variability: $\mathrm{Cu}$ (min. and max.: 0.1-19.8 ppm), Zn (0.1-8 ppm), Sr (0.5-21.8 ppm), $\mathrm{Y}(1.2-14.1 \mathrm{ppm}), \mathrm{Zr}(0.7-13.5 \mathrm{ppm})$ and $\mathrm{Nb}(0.3-4.7 \mathrm{ppm})$.

Similar to the hematitite, the values of some trace elements, such as $\mathrm{V}, \mathrm{Ni}$, $\mathrm{Co}, \mathrm{Y}$ and $\mathrm{Ba}$ from samples collected in the eastern domain, are very distinct from the values from the western domain.

\subsection{Rare Earth Elements (REEs)}

In hematitite samples, the sum of REE contents average $26.85 \mathrm{ppm}$. The values for light REE (LREE; La to Eu) in all samples vary between 2.39 and 200.34 ppm and are 4 times higher than the heavy REE (HREE; Gd to Lu) which values range from 0.41 to $8.74 \mathrm{ppm}$. In itabirite samples the total content of REE is in average of around $16.91 \mathrm{ppm}$
(Table 1). The abundance of LREE is approx. $15.23 \mathrm{ppm}$, ranging from 1.71 to $63.83 \mathrm{ppm}$, whereas, the total content of HREE sums up to $1.68 \mathrm{ppm}$ (0.34-5.01 ppm). All samples show an increase in the LREE content relative to the HREE content, which is more pronounced in the hematitite samples. To evaluate the degree of fractionation of LREE to HREE, REE's were normalized to chondrites (CN) (Evensen et al., 1978). The shape of the distribution of (REEs) $_{\mathrm{CN}}$ shows nearly horizontal patterns with relatively slight high fractionation of LREE to HREE and this was similar for both hematitite and itabirite (Fig.4). LREE fractionation was determined by the ratio $(\mathrm{La} / \mathrm{Sm})_{\mathrm{CN}}$ and HREE fractionation was obtained by the ratio $(\mathrm{Gd} / \mathrm{Yb})_{\mathrm{CN}}$. In the hematitite LREE fractionation ratio $(\mathrm{La} / \mathrm{Sm})_{\mathrm{CN}}$ presents an average of 5.3 (Table 1), whereas, the $\operatorname{ratios}(\mathrm{Gd} / \mathrm{Yb})_{\mathrm{CN}}$ and $(\mathrm{Sm} / \mathrm{Yb})_{\mathrm{CN}}$ have an average value of 1.4 and 1.6 respectively. For the itabirite, the $(\mathrm{La} / \mathrm{Sm})_{\mathrm{CN}}$ ratio presents an average of 5.8, whereas, the $(\mathrm{Sm} / \mathrm{Yb})_{\mathrm{CN}},(\mathrm{Gd} / \mathrm{Yb})_{\mathrm{CN}}$ ratios have an average of 2.1 and 1.9 , respectively (Table 1). The bulk fractionation degree of LREE to HREE was determined for the hematitite and itabirite samples by the ratio of $(\mathrm{La} / \mathrm{Yb})_{\mathrm{CN}}$ which gave averages of 7.7 and 7.3, respectively. Their ratio reaches higher values in some samples, mostly those located in the eastern domain of QF region. The values for the Eu anomaly $\left(\mathrm{Eu} / \mathrm{Eu}^{*}\right)$ are slightly positive and variable in all the samples collected in QF mines.

\section{Discussion}

The amount of iron and silica in this rock is larger than 99 weight $\%$. In the hematitite type, silica is less than $1 \%$ in weight, making these rocks a nearly pure hematite iron ore.

This study indicates that the iron formation from the QF region shares some characteristics with other known IFs around the world. The banding of the itabirite in the QF shares some characteristics similar to the Hamersley Basin in Australia, the Orissa region of India and those of South Africa (James, 1954; Cole, 1981). 
Moustafa Selmi et al.

Table 1 - Trace and rare earth elements (in ppm) of hematitite and itabirite samples $(\mathrm{H})$ hematitite, (I) itabirite, the rest of sample names refer to the mines listed in Figure 1.

TRACE ELENENTS - HEMATITITE

\begin{tabular}{|c|c|c|c|c|c|c|c|c|c|c|c|c|c|c|c|c|c|c|c|}
\hline ppm & BMF & MPC & $\mathrm{ECM}$ & FaA & MFN & $\mathrm{HFN}_{2}$ & HaL, & $\mathrm{HAL}_{2}$ & हMM, & $\mathrm{HUM}_{2}$ & HEZ & $\mathrm{Hez}_{2}$ & HTo & HCE & 100 & $\mathrm{HPQ}_{2}$ & HDC. & $\mathrm{HDC}_{1}$ & म०त्य \\
\hline $\mathrm{V}$ & 37 & 18 & $5 T$ & 69 & 17 & 25 & 42 & 670 & 10 & 80 & 96 & 50.9 & 37 & 46 & 4) & 370 & 74 & 370 & 22 \\
\hline $\mathrm{Co}$ & 4.7 & 14.3 & 3.8 & 6.6 & 14.2 & 5.8 & 113 & 20.9 & 6.0 & 4.5 & 5.6 & 18.6 & 6.3 & 20.3 & 6.5 & 2.3 & 6.2 & 9.2 & 11.3 \\
\hline $\mathrm{Ni}$ & \begin{tabular}{|l|}
37.3 \\
\end{tabular} & 6.3 & \begin{tabular}{|l|}
30.7 \\
\end{tabular} & 1.7 & 4.0 & 0.9 & 2.6 & 13.8 & 1.5 & 4.2 & 1.4 & 3.0 & 1.8 & 0.9 & 1.0 & 1.0 & 0.9 & 0.4 & 1.1 \\
\hline $\mathrm{Cu}$ & 6.2 & 0.9 & 7.8 & 2.0 & 0.6 & 0.5 & 2.9 & 3.5 & 0.5 & 1.9 & 0.1 & 6.0 & 2.3 & 0.3 & 4.6 & 10.5 & 19 & 2.4 & 3.4 \\
\hline $\mathrm{Zn}$ & 5.0 & 3.0 & 6.0 & 3.0 & 2.0 & 1.0 & 2.0 & 50.0 & 2.0 & 3.0 & 1.0 & 6.0 & 1.0 & 1.0 & 1.0 & 1.0 & 2.0 & 1.0 & 1.0 \\
\hline $\mathrm{Ab}$ & 0.3 & 0.7 & 0.6 & 03 & 0.3 & 0.3 & 03 & 0.3 & 03 & 0.7 & 0.3 & 8.0 & 03 & 0.3 & 03 & 0.3 & 03 & 0.3 & 0.3 \\
\hline 5 & 5.5 & 1.5 & 102 & n.1 & 10 & 0.3 & 3.7 & 22.7 & 0.3 & 0.0 & 3.7 & 3.6 & $2 \pi$ & 14 & 13 & 1.9 & 2.7 & 10 & 3.5 \\
\hline $\mathbf{Y}$ & 82 & 2.8 & 10. & 31 & 34 & 8.6 & 135 & 45.8 & 74 & 6. & 16.8 & 75 & 47 & 79 & 44 & 1.1 & 83 & 27 & 21 \\
\hline$z$ & 20 & 4.1 & 4.4 & 3.4 & 9.5 & 3.6 & 1.7 & 25.1 & 4.4 & 3.7 & 4.0 & 15.3 & 2.7 & 11.4 & 2.3 & 3.9 & 18.8 & 12.7 & 6.2 \\
\hline $\mathrm{Nb}$ & 11.3 & 0.3 & 9.2 & 0.3 & 0.6 & 0.3 & 0.3 & 1.8 & 0.3 & 0.3 & 0.3 & 0.5 & 0.3 & 0.3 & 0.3 & 0.3 & 0.9 & 0.3 & 0.3 \\
\hline $\mathrm{Ba}$ & 29 & 2.2 & 28.3 & \begin{tabular}{|l|}
32.3 \\
\end{tabular} & 7.8 & 1.9 & 5.8 & 11.0 & 8.2 & 7.3 & 4.2 & 10.2 & 2.8 & 35.2 & 12.1 & 12.3 & 3.7 & 28.5 & 4.2 \\
\hline $\mathrm{Hf}$ & 0.3 & 0.3 & 0.3 & 0.3 & 0.3 & 0.3 & 0.3 & 0.3 & 0.3 & 0.3 & 0.5 & 0.6 & 0.3 & 0.3 & 0.3 & 0.3 & 0.3 & 0.3 & 0.3 \\
\hline $\mathrm{Ta}$ & 0.1 & 0.1 & 0.1 & 0.1 & 0.1 & 0.1 & 0.2 & a. 1 & 0.1 & 0.1 & 0.1 & 0.1 & 0.1 & 0.3 & 0.3 & 0.1 & 0.1 & 0.2 & 0.1 \\
\hline ETE & 122 & 1EA 0 & 1080 & 130 & 608 & 23.6 & 86.6 & 252 & 41.3 & 32.9 & 1338 & 133 & 624 & 128 & 775 & 72 & 124 & 96 & 6.1 \\
\hline RACE RLI & NENT: & S-ITAI & nigitr & & & & & & & & & & & & & & & & \\
\hline epm & IT & IAV & $1 \mathrm{CO}$ & $\mathbb{P} \mid$ & ICM & ITA & $I P C$ & IMF & 1 TO & 108 & ICE & $\mathrm{ICH}$ & \begin{tabular}{|l|} 
MIN \\
\end{tabular} & MAX & AVG & & & & \\
\hline $\mathrm{v}$ & 16.0 & 2.0 & 18.0 & 9.0 & 10.0 & 47.0 & 12.0 & 55.0 & 2.5 & 7.0 & 21.0 & 41.0 & 2.5 & 56.0 & 20.6 & & & & \\
\hline Co & 23 & 43.0 & 20.7 & 34.3 & 34.2 & 2.1 & 1.1 & 1.3 & 20.5 & 25.6 & 31.2 & 31.3 & 1.1 & 43.0 & 21.8 & & & & \\
\hline Ni & 22.3 & 3.2 & 3.3 & 38 & 6.5 & 42.1 & 13.4 & 33.4 & 13 & 0.8 & 1.2 & 0.4 & 0.4 & 42.1 & 113 & & & & \\
\hline $\mathrm{Cu}$ & 3.18 & 0.7 & 0.1 & 04 & 19.8 & 9.0 & 3.6 & 5.5 & 0.7 & 0.7 & 0.4 & 20 & 0.1 & 19.8 & 39 & & & & \\
\hline $\mathrm{Zn}$ & 20 & 2.0 & 1.0 & 10 & 20 & 30 & 2.8 & 30 & 10 & 0.1 & 1.0 & 01 & 0.1 & 10 & 2.8 & & & & \\
\hline$R b$ & 0.3 & 0.3 & 0.6 & 0.3 & 0.3 & 1.2 & 0.3 & 1.1 & 0.3 & 0.3 & 0.3 & 0.3 & \begin{tabular}{|l|}
0.3 \\
\end{tabular} & 1.2 & 0.5 & & & & \\
\hline $8 r$ & 0.8 & 10.3 & 2.8 & 0.9 & 21.8 & 3.9 & 1.7 & 4.6 & 0.6 & 3.1 & 2.8 & 2.1 & \begin{tabular}{|l|l}
0.5 \\
\end{tabular} & 21.8 & 4.6 & & & & \\
\hline$Y$ & 2.6 & 7.9 & 4.0 & 2.5 & 8.4 & 5.8 & 12 & 4.2 & 3.3 & 14.1 & 1.8 & 3.9 & 12 & 14.1 & 6.0 & & & & \\
\hline $2 x$ & 1.3 & 1.4 & 2.2 & 0.9 & 13.5 & 1.5 & 12 & B.1 & 1.4 & 0.7 & 1.4 & 2.5 & 0.7 & 13.5 & 3.0 & & & & \\
\hline Nb & 25 & 0.3 & 0.3 & 03 & 0.7 & 4.7 & 2.0 & 38 & 03 & 0.3 & 0.3 & 0.3 & 03 & 4.7 & 13 & & & & \\
\hline Ba & 23 & 3.5 & 192 & 03 & 3.6 & 17.1 & 5.6 & 6.1 & 5.7 & 133 & 1.3 & 21.7 & 0.3 & 63.1 & 133 & & & & \\
\hline If & 03 & 0.3 & 0.3 & 03 & 0.3 & 0.3 & 03 & 03 & 03 & 9.3 & 0.3 & 0.3 & 03 & 0.3 & 0.3 & & & & \\
\hline $\mathrm{Ta}$ & 0.1 & 0.5 & 0.5 & 0.4 & 0.3 & 0.1 & 0.1 & 0.1 & 0.3 & 0.3 & 0.5 & 0.4 & 0.1 & 0.5 & 0.3 & & & & \\
\hline ZTE & 57 & 89.3 & 82 & 54.2 & 128.4 & 138.8 & 48.5 & 187.2 & 38.1 & 68.6 & 642 & 106.3 & 38.1 & 183.9 & 87.8 & & & & \\
\hline$\triangle A F E E A$ & THELE & EMENT: & 8. HER & MATIII & ITE & & & & & & & & & & & & & & \\
\hline ppm & HINP & HPC & FicM & FeA & $\mathrm{HrN}_{1}$ & $\mathrm{HrN}_{2}$ & HAL, & $\mathrm{HAL}_{2}$ & Finn, & $\mathrm{HIM}_{2}$ & $\mathrm{H} F \mathrm{Z}_{1}$ & $\mathrm{HIZ} \mathrm{Z}_{2}$ & HTo & \begin{tabular}{|l|} 
HCE \\
\end{tabular} & $F 0_{1}$ & $\mathrm{HPO}_{3}$ & HDC & HDC & मित्न \\
\hline $\mathrm{L}=$ & 24 & 2 & 2.7 & 1 & 2.5 & 0.5 & 3.1 & 32.8 & 31 & 4.5 & 2 & 5.4 & 14.3 & 1.5 & 5.8 & 4.2 & 42 & 2.1 & 0.5 \\
\hline Ce & 5 & 3.7 & 4.7 & 14 & 31 & Q.P & 69 & 1043 & 32 & 39 & 66 & 9 & 2210 & 2.8 & 37 & 67 & 72 & 37 & 1.2 \\
\hline $\mathrm{Pr}$ & 0.73 & 0.35 & 0.5 & \begin{tabular}{|l|}
0.17 \\
\end{tabular} & 0.65 & 0.13 & 1.04 & 9.44 & 0.55 & 0.67 & 0.61 & 0.9 & 2,83 & 0.27 & 1 & 079 & 0.91 & 0.6 & 016 \\
\hline Nd & 3.2 & 0.9 & 2.4 & 1.4 & 1.8 & 0.4 & 42 & 33.5 & 2.6 & 2.5 & 2.6 & 3 & 11.5 & 1 & 4.3 & 3.1 & 4.1 & 2.8 & 0.6 \\
\hline $8 m$ & 1 & 0.3 & 0.6 & 0.2 & 0.3 & 0.2 & 1.3 & 6.5 & 0.4 & 0.4 & 1.2 & 0.8 & 2 & 0.3 & 0.9 & 0.8 & 1.1 & 0.5 & 0.2 \\
\hline $\mathrm{Eu}$ & 0.27 & 0.08 & 0.23 & 0.1 & 0.05 & 0.03 & 0.45 & 1.51 & 0.12 & 0.14 & 0.41 & 0.4 & 0.5 & 0.08 & \begin{tabular}{|l|}
6.14 \\
\end{tabular} & 0.2 & 0.4 & 0.1 & $\div 0.05$ \\
\hline Gd & 123 & 0.22 & 1. 102 & 0.32 & 028 & 0.24 & 1.51 & 4.41 & 0.4 & 0.40 & 1.38 & 0.5 & \begin{tabular}{|l|}
.85 \\
\end{tabular} & 0.2 & $a .71$ & 0 का & 1.18 & 0.4 & 0.25 \\
\hline Tb & 0.2 & Qns & 0.16 & 0.06 & am & ans & 0.24 & 0.75 & 0.06 & 0.0 & 0.26 & 0.1 & 0.76 & ans & 0.00 & nos & 02 & 0.1 & D.ns \\
\hline Dy & 107 & 0.37 & \begin{tabular}{|l|}
1.14 \\
\end{tabular} & 0.75 & 0.29 & 054 & 1.42 & 492 & 0.5 & 054 & 155 & 9.9 & 1.06 & 0.31 & 0.56 & 037 & 1.12 & 95 & \begin{tabular}{|l|}
027 \\
\end{tabular} \\
\hline $\mathrm{Ho}$ & \begin{tabular}{|l|}
0.29 \\
\end{tabular} & 0.07 & \begin{tabular}{|l|l|}
0.26 \\
\end{tabular} & $0,00 \mid$ & 0.05 & \begin{tabular}{|l|l|}
0.17 \\
\end{tabular} & 0.35 & 1.09 & 0.16 & 0.1 & 0.38 & 0.2 & \begin{tabular}{|l|}
0.16 \\
\end{tabular} & 0.1 & \begin{tabular}{|l|}
0.12 \\
\end{tabular} & 005 & 0.25 & 0.1 & -0.08 \\
\hline EI & 0.8 & 0.22 & \begin{tabular}{|l|}
0.77 \\
\end{tabular} & 0.21 & 0.25 & 0.65 & 1.01 & 3.23 & 0.63 & 0.4 & 1.35 & 0.9 & \begin{tabular}{|l|}
0.45 \\
\end{tabular} & 0.33 & 0.36 & 0.12 & 0.73 & 0.2 & 0.15 \\
\hline $\mathrm{Tm}$ & \begin{tabular}{|l|}
0.12 \\
\end{tabular} & $\infty 0.06$ & \begin{tabular}{|l|}
0.15 \\
\end{tabular} & 0.06 & $\odot 0.06$ & \begin{tabular}{|l|}
0.11 \\
\end{tabular} & 0.17 & 0.58 & 0.11 & 0.06 & 0.22 & 0.2 & \begin{tabular}{|l|}
0.09 \\
\end{tabular} & 0.08 & \begin{tabular}{|l|}
0.09 \\
\end{tabular} & $<0.05$ & 0.11 & 0.1 & 0.15 \\
\hline $\mathrm{Yb}$ & 0.87 & 0.35 & 0.88 & 0.24 & 0.34 & 0.50 & 0.91 & 3.36 & 0.88 & 0.4 & 1.35 & 1.2 & \begin{tabular}{|l|}
0.34 \\
\end{tabular} & 0.43 & \begin{tabular}{|c|}
0.48 \\
\end{tabular} & 0.17 & 1.4 & 0.4 & 0.16 \\
\hline $\mathrm{Lu}$ & 0.12 & D.16 & D. & 0.48 & 0 as & 0.15 & 0.04 & 0.05 & 0.03 & 0.06 & 0.07 & 0.2 & 0.15 & 0.16 & 0.04 & 025 & 0.05 & 0.1 & 004 \\
\hline ILREE & $13 \mathrm{~g}$ & 7.56 & 12.15 & A.ES & 6.93 & 253 & 16.74 & $190 \mathrm{cos}$ & 10.45 & 12.82 & 15.04 & 203 & $5.5 \mathrm{~g}$ & 6.23 & 16.84 & 18.56 & 1825 & 103 & 3.18 \\
\hline УHAEE & 327 & 1.17 & 321 & 1,85 & 073 & 1.57 & 240 & 1401 & 1,78 & 1.1 & 335 & 3.6 & 2.24 & 105 & $1 / 65$ & 059 & 28 & 9.9 & 0.5 \\
\hline IREE & 17.3 & 8.78 & 15.52 & 6.06 & B.95 & 4.63 & 22.64 & 213.57 & 12.91 & 14.33 & 19.97 & 24 & 50.08 & 7.67 & 18.29 & 17.62 & 22.94 & 11.7 & 3.93 \\
\hline EUEV & 1.1 & 1.4 & 1.35 & 1.8 & 1.7 & 1.5 & 1.5 & 1.3 & 1.4 & 1.5 & 1.5 & 2 & 1.3 & 1.5 & 0.8 & 123 & 1.6 & 1.3 & $\frac{1}{1}$ \\
\hline Lar $8 \mathrm{~mm}$ & 24 & 6.7 & 4.5 & 5 & 2.5 & 9.3 & 2.4 & 6.1 & 78 & 11.3 & 1.7 & 6.8 & 7.15 & 2.3 & 6.4 & 5.3 & 3.8 & 4.2 & 3.5 \\
\hline$(\mathrm{Gd} / \mathrm{Yb})_{4}$ & 1.4 & 0.6 & 1.2 & 1.3 & 0.3 & 0.8 & 1.7 & 1.3 & 0.5 & 1.3 & 1 & 0.7 & 49 & 1.7 & 1.5 & 3.5 & 0.8 & 1 & 1.6 \\
\hline Larybs & $2 B$ & 5.7 & 3.1 & 42 & 0.5 & 8.2 & 34 & 11.7 & 38 & 113 & 1.5 & 4.5 & 421 & 3 & 12.1 & 21 & 3 & 5.3 & 4.4 \\
\hline$(5 \mathrm{~m} / \mathrm{rb}$ & 1.2 & 1.0 & 0.77 & 0.5 & 0.6 & 1.0 & 1.6 & 33 & 0.7 & 1.1 & 1.8 & 0.9 & 4.1 & 1.5 & 2.1 & 5.2 & 10 & 14 & 1.3 \\
\hline REE EA & HE & ENT & 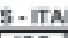 & IARITI & & & & & & & & & & & & & & & \\
\hline epm & $1 \mathrm{~T}$ & IAV & 100 & $\mathbb{P} \mid$ & ICM & ITA & $I F C$ & IMF & ITO & 108 & ICE & $\mathrm{ICH}$ & \begin{tabular}{|l|} 
MIN \\
\end{tabular} & \begin{tabular}{|l|} 
MAX \\
\end{tabular} & AVG & & & & \\
\hline La & 1 & 1.3 & 1.6 & 0.6 & 4.2 & 4.5 & 0.6 & 28 & 1.5 & 16.1 & 0.5 & 0.8 & 0.5 & \begin{tabular}{|l|}
16.1 \\
\end{tabular} & 3.75 & & & & \\
\hline Ce & 1.7 & 2.6 & 2.0 & 0.8 & 5.9 & 7.5 & 0.8 & 8.2 & 1.8 & 19.8 & 1.2 & 1.4 & \begin{tabular}{|l|l|}
0.6 \\
\end{tabular} & \begin{tabular}{|l|}
19.6 \\
\end{tabular} & 5.15 & & & & \\
\hline Pr & 0.2 & 0.35 & 0.45 & 0.1 & 0.53 & 0.5 & 0.15 & 0.95 & 0.25 & 4.12 & 0.18 & 0.24 & 0.1 & 4.12 & 0.900 & & & & \\
\hline Nd & 0.5 & 1.8 & 2.1 & 0.5 & 2.5 & 3.6 & प11 4 & 4 & 09 & 19.3 & 0.6 & 1.3 & 0.5 & 198 & $4.4 \mathrm{a}$ & & & & \\
\hline $5 \mathrm{~m}$ & 0.2 & 0.5 & 9.6 & 01 & 07 & 9.6 & 0.7 & 08 & 01 & 39 & 0.3 & 0.5 & 01 & $Q .9$ & 0.43 & & & & \\
\hline $\mathrm{Eu}$ & $<0.05$ & \begin{tabular}{|l|}
0.17 \\
\end{tabular} & 0.16 & 50.00 & 0.16 & 0.16 & $\infty 0.06$ & 0.19 & 40.05 & 1.27 & 013 & 0.14 & 0.13 & \begin{tabular}{|l|}
1.27 \\
\end{tabular} & 0.378 & & & & \\
\hline Gd & 0.23 & \begin{tabular}{|l|l|}
0.62 \\
\end{tabular} & 0.63 & \begin{tabular}{|l|}
0.19 \\
\end{tabular} & 0.69 & 0.57 & 0.06 & 0.86 & 0.28 & 3.69 & 0.24 & 0.8 & \begin{tabular}{|l|}
0.06 \\
\end{tabular} & \begin{tabular}{|l|}
3.69 \\
\end{tabular} & 0.56 & & & & \\
\hline $\mathrm{Tb}$ & \begin{tabular}{|l|}
0.03 \\
\end{tabular} & \begin{tabular}{|l|}
0.11 \\
\end{tabular} & 0.13 & \begin{tabular}{|l|}
0.03 \\
\end{tabular} & 0.13 & 0.16 & 0.09 & 0.11 & 0.07 & 0.52 & 0.05 & 0.1 & \begin{tabular}{|l|}
0.09 \\
\end{tabular} & \begin{tabular}{|l|}
0.52 \\
\end{tabular} & 0.14 & & & & \\
\hline Dy & 0.23 & \begin{tabular}{|l|}
0.53 \\
\end{tabular} & 0.58 & \begin{tabular}{|l|}
0.41 \\
\end{tabular} & 0.92 & 0.75 & $\infty 0.06$ & 0.54 & 0.32 & 2.45 & 0.12 & 0.58 & \begin{tabular}{|l|}
0.12 \\
\end{tabular} & 245 & 0.78 & & & & \\
\hline $\mathrm{Ho}$ & 0.08 & \begin{tabular}{|l|}
0.16 \\
\end{tabular} & 0.13 & $0.00 \mid$ & 0.21 & 0.19 & -0.05 & 0.00 & 0.06 & 0.41 & $<0.60$ & 0.12 & 0.06 & 0.41 & 0.18 & & & & \\
\hline Er & 021 & \begin{tabular}{|l|l|}
0.47 \\
\end{tabular} & Qns & 0.32 & 031 & 069 & 0.05 & 0.31 & 0.73 & 1.⿴囗十 & 0.2 & 0.24 & 0.06 & 1.m & 0.44 & & & & \\
\hline$T \mathrm{~m}$ & $<0,05$ & $00 \mathrm{~s}$ & \begin{tabular}{|l|l}
015 \\
\end{tabular} & 0,05 & 81 & 007 & 60,05 & 0.06 & 0.07 & 016 & $\infty 0.05$ & 20.05 & 0,05 & 0.16 & 0095 & & & & \\
\hline $\mathrm{Yb}$ & 0.24 & 0.63 & 0.32 & 0.82 & 0.63 & \begin{tabular}{|l}
0.37 \\
\end{tabular} & 0.15 & 0.31 & 0.29 & 0.83 & 60.05 & \begin{tabular}{|l|}
0.29 \\
\end{tabular} & \begin{tabular}{|l|}
0.15 \\
\end{tabular} & 0.83 & 0.43 & & & & \\
\hline Lu & 0.12 & 0.04 & 0.08 & 0.08 & 0.18 & 0.04 & 0.08 & 0.13 & 0.1 & 0.04 & 0.08 & 0.14 & 0.04 & \begin{tabular}{|l|}
0.14 \\
\end{tabular} & 0.08 & & & & \\
\hline IIREE & 3.83 & 7.45 & $B .32$ & 2.09 & \begin{tabular}{|l|}
15.18 \\
\end{tabular} & 17.73 & 1.71 & 15.9 & 4.63 & 63.53 & 3.13 & 5.18 & \begin{tabular}{|l|}
1.71 \\
\end{tabular} & \begin{tabular}{|l|}
83.63 \\
\end{tabular} & 16.23 & & & & \\
\hline YARET & 0.86 & 1.92 & 200 & 1.5 & 205 & 1.91 & 0.34 & 1.44 & 1.16 & 5.01 & 0.47 & 1.47 & 0.34 & \begin{tabular}{|l|}
5.01 \\
\end{tabular} & 1.68 & & & & \\
\hline IREE & 4.72 & 2.37 & 10.61 & 3.50 & 17.00 & 12.79 & 2.06 & 17.45 & 5.79 & 6s.21 & ses & 56 & 2.50 & ED.21 & 16.91 & & & & \\
\hline Eutr: & 1.1 & 1.4 & 12 & 2 & 0.5 & 1.2 & 1.5 & 05 & 3 & 1 & 3.9 & 2 & 1 & 3 & 1.8 & & & & \\
\hline $1 \mathrm{La} 5 \mathrm{~mm}$ & 5 & 2.6 & 2.7 & 6 & 6 & 75 & 6 & 31 & 15 & 39 & 17 & 1.6 & 1.6 & 15 & 58 & & & & \\
\hline$[\mathrm{Gd} / \mathrm{b} \mathrm{h}$ & 1 & 1.2 & 2 & 0.5 & 1.2 & 1.5 & 0.5 & 3 & 1 & 3.9 & 2 & 2.7 & 0.5 & 3.9 & 1.9 & & & & \\
\hline Larbla & 6 & 2.6 & 5.3 & 3 & 7 & \begin{tabular}{|l|}
11.3 \\
\end{tabular} & 3 & 9.3 & 5 & 16.8 & 6 & 2.7 & 2.6 & 16.8 & 73 & & & & \\
\hline $8 \mathrm{~m}^{2} \mathrm{rb}$ & 0.9 & 1.0 & 2.3 & 0.7 & 1.3 & 1.8 & 0.8 & 32 & 0.5 & 4.7 & 6.7 & 1.2 & 0.5 & 6.7 & 2.1 & & & & \\
\hline
\end{tabular}


In relation to trace elements, the mean values for hematitite and itabirite are comparable to averages reported by Spier et al. (2007), Lindenmayer et al. (2001), and Klein and Ladeira (2000) (Table. 2). The analyzed data presents lower concentrations in comparison to the data from Klein and Ladeira (2000), but more or less similar to the values found by Spier et al. (2007). However when compared with other IFs in the world, both hematitite and itabirite show lower average contents of trace elements (Table 2). Both hematite and itabirite samples have a lower concentration of the $\mathrm{Ba}$ element than the data obtained from Klein and Ladeira (2000) and Spier et al. (2007) in the QF region. Also the same result is obtained in comparison to the Ba data of IFs around the world.

The values for the V, Co, Ni elements for the Lake Superior region (Animikie IF) are higher than those of the itabirite of the QF. The $\mathrm{V}$ contents in the hematitite are higher than in the itabirite, but are not very distinct from the data set from Nigeria (Adekoya, 1998). In comparison to the Canadian Algoma-type Ifs data (Gross and Macleod, 1980), some

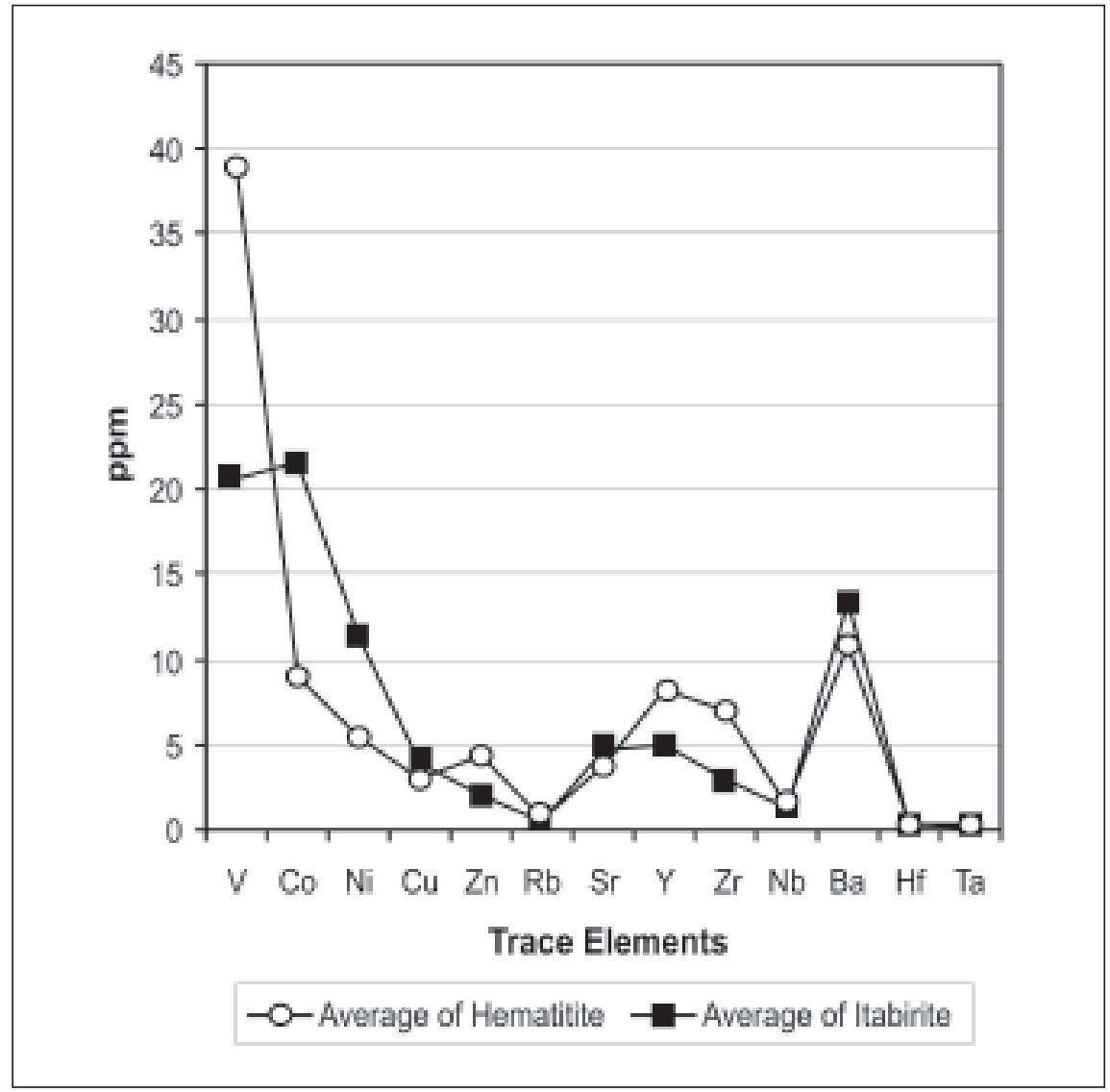

Figure 3 - Plot of the average concentration of trace-elements of the hematitite and itabirite samples.

Table 2 - Average of trace element contents in the iron formation of this study compared with some iron formations of the QF region and from other parts of the world.

\begin{tabular}{|c|c|c|c|c|c|c|c|c|}
\hline \multirow{2}{*}{ ppm } & \multicolumn{2}{|c|}{ QF This Study } & \multirow{2}{*}{$\begin{array}{c}\text { QF" }^{2} \\
\text { Itabirite }\end{array}$} & \multirow{2}{*}{$\begin{array}{c}\text { QF }^{\mathrm{b}} \\
\text { Itabirite }\end{array}$} & \multirow{2}{*}{$\begin{array}{l}\text { Superior }^{g} \\
\text { BIF }\end{array}$} & \multirow{2}{*}{$\begin{array}{c}\text { Algoma }^{d} \\
\text { BIF }\end{array}$} & \multirow{2}{*}{$\begin{array}{c}\text { Nigeria }{ }^{\circ} \\
\text { BIF }\end{array}$} & \multirow{2}{*}{$\begin{array}{c}\text { Orissa India' } \\
\text { BIF }\end{array}$} \\
\hline & Hematitite & Itabirite & & & & & & \\
\hline V & 39 & 20.6 & 22.6 & - & 30.0 & 97.0 & 44.0 & 30.0 \\
\hline Co & 9 & 21.6 & - & 249.0 & 27.0 & 38.0 & 100.0 & 35.0 \\
\hline $\mathrm{Ni}$ & 5.5 & 11.3 & 10.5 & 20,0 & 32.0 & 83.0 & $<10$ & 15.0 \\
\hline $\mathrm{Cu}$ & 2.9 & 3.9 & $<1.0$ & 33.8 & 10.0 & 96.0 & $<10$ & 10.0 \\
\hline $\mathrm{Zn}$ & 4.4 & 2.0 & - & 42.3 & 2.0 & 33.0 & 26.0 & - \\
\hline $\mathbf{R b}$ & 0.6 & 0.5 & $<1.0$ & 32.9 & - & - & 20.0 & - \\
\hline $\mathrm{Sr}$ & 3.7 & 4.6 & 5.0 & 10.3 & 42.0 & 83.0 & 51.0 & 15.0 \\
\hline $\mathbf{Y}$ & 8.2 & 5 & 3.9 & 4.8 & 41.0 & 54.0 & 22.0 & - \\
\hline $\mathrm{Zr}$ & 7.0 & 3 & 12.0 & 2.5 & 60.0 & 84.0 & 60.0 & 10.0 \\
\hline $\mathrm{Nb}$ & 1.4 & 1.3 & 0.8 & 6.4 & - & - & 5.0 & - \\
\hline $\mathrm{Ba}$ & 10.8 & 13.3 & 15.4 & 55.4 & 180.0 & 170 & 293.0 & 70.0 \\
\hline $\mathrm{Hf}$ & 0.3 & 0.3 & $<0.1$ & 0.1 & - & - & - & - \\
\hline $\mathrm{Ta}$ & 0.1 & 0.3 & - & 0.1 & - & - & - & - \\
\hline ¿TE & 92.6 & 87.9 & 72.3 & 457.3 & 424.0 & 738.0 & 621.0 & 185.0 \\
\hline
\end{tabular}

a Paleoproterozoic banded iron formation (Itabirite of Caue Fm) (Spier et al., 2007).

${ }^{b}$ Itabirite from Caue Fm (Klein and Ladeira, 2000).

c Lake superior silicate facies iron-formation (Animikie) (Gross and Macleod, 1980, Table 3).

d Algoma oxide facies iron-formation (Gross and Macleod, 1980, Table 3).

${ }^{\text {e }}$ Maru iron formation (oxide facies) (Adeloya, 1998).

${ }^{f}$ Orissa iron-formation (oxide facies), India (Majumder et al., 1982, Table 3). 
Moustafa Selmi et al.

trace element values like $\mathrm{V}, \mathrm{Ba}, \mathrm{Ni}, \mathrm{Co}$, $\mathrm{Nb}, \mathrm{Zr}$ revealed higher values than the data of the studied ore of the QF region.

The trace element values for the Orissa iron formation in India are much higher than the data of the studied ore samples, but the value for the $\mathrm{V}$ element is in the same range as our analyzed data.

In the studied area, the values presented for $\mathrm{Ni}$ and $\mathrm{Cu}$ are much lower in comparison with data for the rest of the QF region, as well as from other banded iron formations (BIFs) around the world (Table 2).

REE systematics in the QF iron formations are in the same range of values found in other similar sequences around the world (Fig. 5). On the average, the total content of REEs is relatively low with a moderate fractionation of light REE (LREE) relative to heavy REE (HREE) (Fig. 4), coupled with slightly positive $\mathrm{Eu}$ anomalies (average value of 1.5 and 1.6 for hematitite and itabirite samples, respectively). As with other Ifs of similar age, theThe majority of the analyzed samples display similar REE systematics and are compatible with the results of Bau and Möller (1993) that indicate that Ifs, independent of their provenance, age, and metamorphic grade, display a similar degree of fractionation of LREE $\left.(\mathrm{La} / \mathrm{Sm})_{\mathrm{CN}}>1\right)($ Table.1).

The sum of REEs of the analyzed samples of this study is higher than the results obtained by Spier (2007) and from the jaspilites of the Carajás formation (Macambira and Schrank, 2002). In comparison to the other BIFs around the world, the itabirite of this study show values more or less similar to the REEs contents of the Surgur belt (Kato et al., 1996) and lower than the Kuruman BIF oxide facies (Klein and Beukes, 1989) (Table 3).

The ratio $(\mathrm{La} / \mathrm{Yb})_{\mathrm{CN}}$ of hematitite and itabirite samples show higher values in comparison to other BIFs around the world (Table 3).

The iron ore samples (oxide lithofacies) collected from the $\mathrm{QF}$ region consist mainly of hematite, magnetite and quartz. The analyzed samples are of two
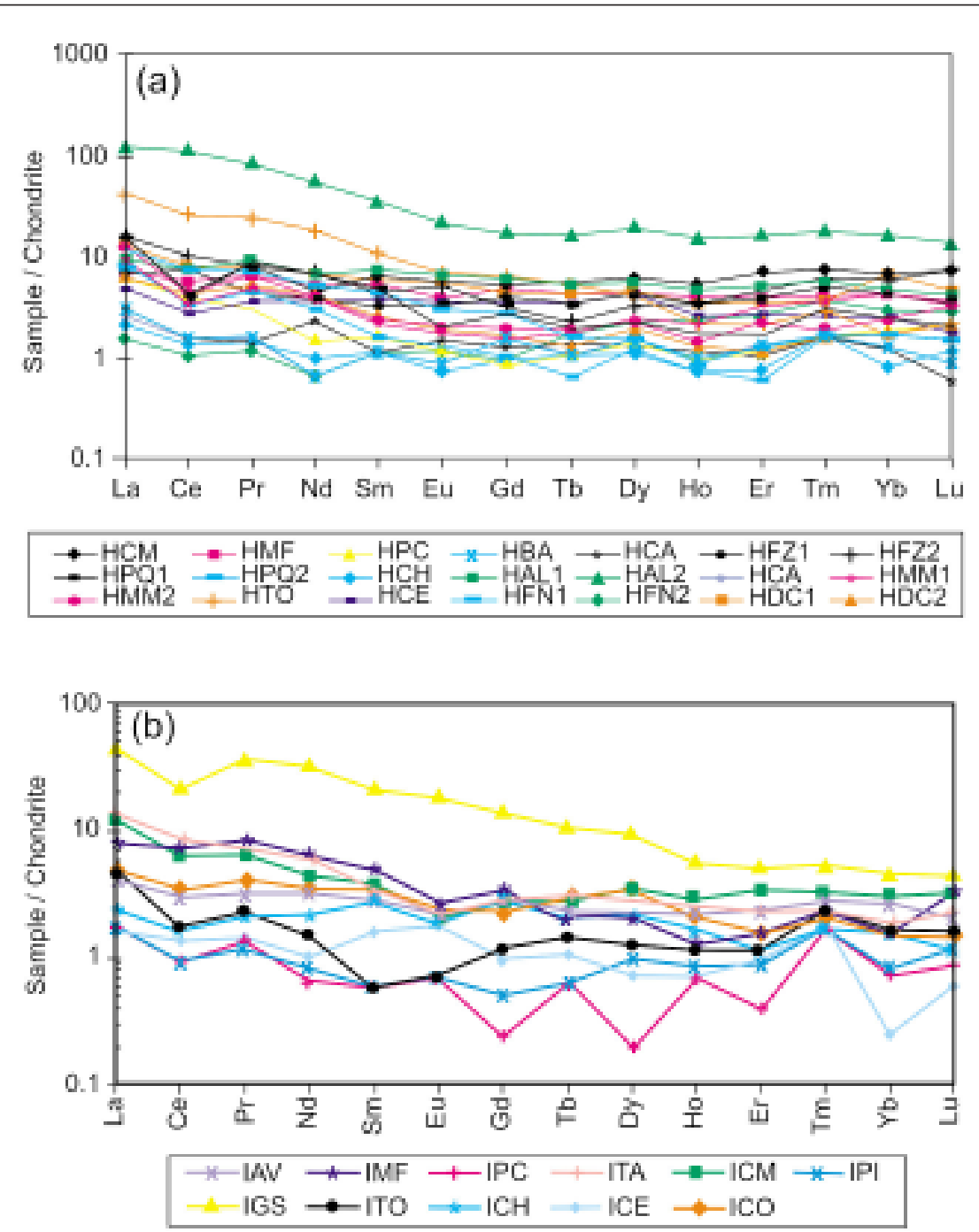

Figure 4 - Chondrite (after Evensen et al., 1978) normalized pattern of rare earth elements (REE) calculated for the hematitite samples (a) and itabirite samples (b).

types: hematitite and itabirite. The hematitite has more than $98 \%$ of $\mathrm{Fe}$, whereas, the itabirite has varied contents of iron and silica, on the average higher than $99 \%$.

The concentrations of trace (mainly transition metals) and rare earth elements of the hematitite and itabirite samples show considerable variability and appear in high values, especially in the eastern domain of the QF region. Particularly recorded was data from samples collected from Dois Córregos, Chacrinha, Gongo Soco, Periquito, Conceição and mines from Alegria.

The samples show low REE abundances and a moderate fractionation ratio of LREE/HREE besides slightly positive Eu anomalies coupled with positive values for the $(\mathrm{La} / \mathrm{Yb})_{\mathrm{CN}},(\mathrm{La} / \mathrm{Sm})_{\mathrm{CN}}$.ratios.

\section{Acknowledgments}

Special thanks go to all my colleagues in Micro-Lab- UFOP for their assistance and valuable discussions.

\section{References}

ADEKOYA, J.A. The geology and geochemistry of the Maru Banded IronFormation, northwestern Nigeria. Journal of African Earth Sciences, 27, p. 241-257, 1998. 


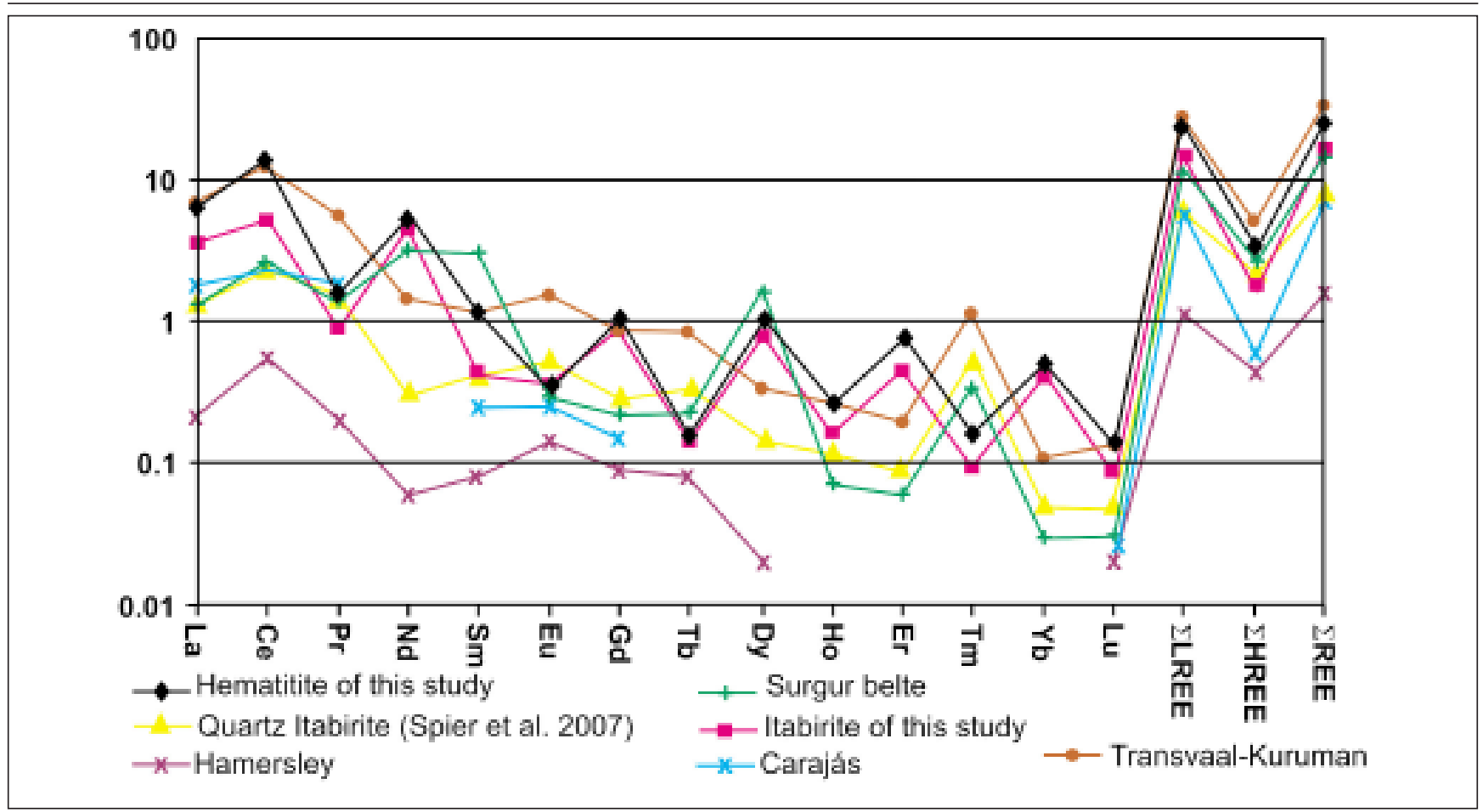

Figure 5 - Graph showing rare earth element content of the analyzed samples compared with some iron formations of the QF region and from other parts of the world (data obtained from Table 3).

Table 3 - Average of rare earth element contents in the iron formation of this study compared with some iron formations of the QF region and from other parts of the world.

\begin{tabular}{|c|c|c|c|c|c|c|}
\hline \multirow{2}{*}{ ppm } & \multicolumn{2}{|c|}{ QF This Study } & \multirow{2}{*}{$\begin{array}{c}\mathrm{QF}^{*} \\
\text { Itabirite }\end{array}$} & \multirow{2}{*}{$\begin{array}{c}\mathrm{QF}^{\mathrm{b}} \\
\text { Itabirite }\end{array}$} & \multirow{2}{*}{$\begin{array}{c}\text { Superior }^{2} \\
\text { BIF }\end{array}$} & \multirow{2}{*}{$\begin{array}{c}\text { Algoma } \\
\text { BIF }\end{array}$} \\
\hline & Hematitite & Itabirite & & & & \\
\hline La & 6.51 & 3.75 & 1.4 & 0.22 & 7 & 1.37 \\
\hline $\mathrm{Ce}$ & 13.96 & 5.15 & 2.32 & 0.54 & 12.71 & 2.73 \\
\hline $\mathrm{Pr}$ & 1.45 & 0.9 & 1.59 & 0.2 & 5.49 & 1.46 \\
\hline Nd & 5.45 & 4.48 & 0.32 & 0.06 & 1.47 & 3.23 \\
\hline $\mathrm{Sm}$ & 1.22 & 0.43 & 0.43 & 0.08 & 1.13 & 3.05 \\
\hline Eu & 0.34 & 0.37 & 0.54 & 0.14 & 1.512 & 0.3 \\
\hline Gd & 1.04 & 0.86 & 0.3 & 0.09 & 0.85 & 0.22 \\
\hline $\mathrm{Tb}$ & 0.17 & 0.14 & 0.35 & 0.08 & 0.85 & 0.23 \\
\hline Dy & 1.04 & 0.78 & 0.15 & 0.02 & 0.33 & 1.65 \\
\hline Ho & 0.25 & 0.16 & 0.12 & ND & 0.26 & 0.07 \\
\hline Er & 0.76 & 0.44 & 0.09 & $\mathrm{ND}$ & 0.19 & 0.06 \\
\hline $\mathrm{Tm}$ & 0.16 & 0.09 & 0.56 & 0.1 & 1.16 & 0.34 \\
\hline $\mathrm{Yb}$ & 0.48 & 0.43 & 0.05 & ND & 0.11 & 0.03 \\
\hline Lu & 0.13 & 0.08 & 0.05 & 0.02 & 0.13 & 0.03 \\
\hline इLREE & 23.64 & 15.23 & 6.05 & 1.1 & 27.8 & 11.84 \\
\hline ¿HREE & 3.21 & 1.68 & 2.21 & 0.45 & 5.04 & 2.93 \\
\hline IREE & 26.85 & 16.91 & 8.26 & 1.55 & 32.85 & 14.78 \\
\hline$(\mathrm{La} / \mathrm{Yb})_{\mathrm{N}}$ & 7.7 & 7,3 & 0.51 & 0.87 & 0.88 & 0.94 \\
\hline$\left(\mathrm{Eu} / \mathrm{Eu}^{*}\right)_{\mathrm{N}}$ & 1.5 & 1.6 & 1.49 & 1.33 & 1.45 & 2.13 \\
\hline \multicolumn{7}{|c|}{$\begin{array}{l}\text { a Paleoproterozoic banded iron formation (Itabirite of Caue Fm.) (Spier et al., 2007). } \\
\text { b Hamersley banded iron formation (Glikson et al., 2004). } \\
\text { c Transversal Supergroup, Kuruman BIF (oxide facies), (Klein and Beukes, 1989). } \\
\text { d Surgur belt, India (Kato et al., 1996). }\end{array}$} \\
\hline
\end{tabular}


ALIBERT, C., MCCULLOCH, M.T. Rare earth element and neodymium isotopic compositions of the banded ironformations and associated shales from Hamersley, Western Australia. Geochimica et Cosmochimica Acta, 57, p. 187-204, 1993.

ALKMIM, F. F., MARSHAK, S. Transamazonian orogeny in the southern São Francisco Craton Region, Minas Gerais, Brazil: evidence for paleoproterozoic collision and collapse in the Quadrilátero Ferrífero. Precambrian Research, 90, p. 29-58, 1998.

BAU, M., MÖLLER, P. Rare earth element systematics of the chemically precipitated component in Early Precambrian iron formations and the evolution of the terrestrial atmosphere hydrosphere- lithosphere system. Geochim. et Cosmochim. Acta, 57, p. 2239-2249, 1993.

BAU, M., DULSKI, P. Distribution of Y and rare-earth elements in the Penge and Kuruman Iron-Formations, Traansvaal Supergroup, South Africa. Precambrian Research, 79, p. 37-55, 1996.

CHEMALE, F. Jr., ROSIÈRE, C.A., ENDO, I. The tectonic evolution of the Quadrilátero Ferrífero, Minas Gerais, Brazil. Precambrian Research, 65, p. 25-54, 1994.

COLE, M. J. Archean banded ironformations, Yilgarn Block, Western Australia. Economic Geology, 76, p. 1954-1974, 1981.

CORDANI, U.G., KAWASHITA, K., MÜLLER, G., QUADE, H., REIMER, V., ROESER, H. Interpretação tectônica e petrológica de dados geocronológicos do embasamento na borda sudeste do Quadrilátero Ferrífero. Anais da Academia Brasileira de Ciências, 52, p. 785-799, 1980.

DERRY, L.A., JACOBSEN, S.B. The chemical evolution of Precambrian seawater: Evidence from REEs in banded iron formations. Geochim. et
Cosmochim. Acta, 54, p. 2965-2977, 1990.

DORR J. V. N. \& BARBOSA A. L. M. Geology and ore deposits of the Itabira District, Minas Gerais, Brazil. .U. S. Geological Survey Prof. Paper 341-C. Washington, DC, 1963. 110p.

DORR II, J.V.N. Physiographic, stratigraphic and structural development of the Quadrilátero Ferrífero, Minas Gerais, Brazil. U.S. Geological Survey Professional Paper 641-A, 1969. 42p.

EVENSEN, N. M., HAMILTON P.J. and O'NIONS R.K. Rare earth abundances in chondrictic meteorites, Geochimica et Cosmochimica Acta, 42, p. 1199-1212, 1978.

GLIKSON, A.Y., ALLEN, C. Iridium anomalies and fractionated elements pattern in impact ejecta, Brockman iron formation, Hamersley Basin, Western Australia: Evidence for a major a sterio impact in simatic crustal regions of the Early Proterozoic Earth. Earth and Planetary Science Letters, v. 220, p. 247264, 2004.

GROSS, G. A., MACLEOD, C. R. A preliminary assessment of the chemical composition of iron formations in Canada. Canadian Mineralogist, 16, p. 223-229, 1980.

HERZ, N., Metamorphic rocks of the Quadrilátero Ferrífero, Minas Gerais, Brazil. U.S.G.S. Professional Paper 641C. U.S. Geological Survey, U.S.A., p. C1C81, 1978.

JAMES, H.L. Sedimentary facies of ironformations. Econ. Geol., 49, p. 235-293, 1954.

KATO, Y., TAKANORI, K., TAKASHI, K., KUNUGIZA, K., SWAMY, N.S. Rareearth element geochemistry of banded iron formations and associated amphibolite from the Sargur belts, south India. Journal of Southeast Asian Earth Sciences, 14, p. 161-164, 1996.
KLEIN, C., LADEIRA, E.A. Geochemistry and petrology of some Proterozoic banded iron-formations of the Quadrilátero Ferrífero, Minas Gerais, Brazil. Economic Geology, 95, p. 405428, 2000

KLEIN, C., BEUKES, N.J. Geochemistry and sedimentary of a facies transition from limestone to iron formation deposition in the Early Proterozoic Transvaal Supergroup, South Africa. Economic Geology, 84, p. 1733-1774, 1989.

MARSHAK, S., ALKMIM, F.F. Proterozoic contraction/ extension tectonics of the southern São Francisco region, Minas Gerais, Brazil. Tectonics, 8, p. 555-571, 1989.

MAJUMDER, T., HAKRABORTY, K. T., BHATTACHARYYA, A. Geochemistry of banded iron formation, Orissa, India. Mineralium Deposita, 17, p. 107-118, 1982.

MORALES, L., LAGOEIRO, L., ENDO, I. Crystallographic fabric development along a folded polycrystalline hematite, Journal of Structural Geology, 2008. (In press).

PIRES, F.R.M. Textural and mineralogical variations during the metamorphism of the Proterozoic Itabire Iron Formation in the Quadrilátero Ferrífero, Minas Gerais, Brazil. Anais da Academia Brasileira de Ciências, 67, p. 77-105, 1995.

ROSIÈRE C.A., SIEMES H., QUADE H., BROKMEIER, H.G., JANSEN EM. Microstructures, textures and deformation mechanisms in hematite. $\boldsymbol{J}$ Struct Geol., 23, p. 1429-1440, 2001.

SPIER, C.A., OLIVEIRA, S.M.B., SIAL, A.N., RIOS, F.J. Geochemistry and genesis of the banded iron formations of the Cauê Formation, Quadrilátero Ferrífero, Minas Gerais, Brazil. Precambrian Research, 152, p. 170-206, 2007.

Artigo recebido em 03/06/2008 e aprovado em 24/09/2008.

\section{A REM tem novo endereço: Rua Carlos Walter Marinho Campos, 57 Bairro: Vila Itacolomy 35400-000 - Ouro Preto - MG}

